\title{
Protein Degradation by Human Intestinal Bacteria
}

\author{
By G. T. MACFARLANE, ${ }^{*}$ J. H. CUMMINGS ANd C. ALlison \\ MRC Dunn Clinical Nutrition Centre, 100 Tennis Court Road, Cambridge CB2 1QL, UK
}

(Received 25 July 1985; revised 28 October 1985)

\begin{abstract}
Analysis of human gut contents showed that substantial quantities of soluble protein, ammonia and branched chain volatile fatty acids occurred throughout the large intestine $[0 \cdot 1-24 \cdot 4 \mathrm{~g}(\mathrm{~kg}$ contents) $)^{-1}, 7 \cdot 7-66.0 \mathrm{mmol}$ (kg contents) ${ }^{-1}$ and $1.5-11.1 \mathrm{mmol}^{(\mathrm{kg} \text { contents) }}{ }^{-1}$ respectively]. The presence of these metabolites suggested that substantial proteolysis was occurring. In vitro studies showed that casein and bovine serum albumin were partly degraded in slurries of human faeces over a $96 \mathrm{~h}$ incubation period, to produce TCA-soluble peptides, ammonia and volatile fatty acids. Proteolytic activity detected in the stools of five individuals ranged from 3.5 to $19.8 \mathrm{mg}$ azocasein hydrolysed $\mathrm{h}^{-1}(\mathrm{~g} \text { faecal material })^{-1}$. Washed cell and washed particulate faecal fractions accounted for $24-67 \%$ of total activity. The predominant proteolytic bacteria in the faecal samples examined were identified as Bacteroides spp. $\left[1.0 \times 10^{11}-1.3 \times 10^{12}\right.$ (g dry wt faeces) $\left.)^{-1}\right]$ and Propionibacterium spp. $\left[1.2 \times 10^{8}-1.0 \times 10^{10}\right.$ (g dry wt faeces) $\left.{ }^{-1}\right]$. Other proteolytic bacteria which occurred in lesser numbers were identified as belonging to the genera Streptococcus, Clostridium, Bacillus and Staphylococcus. These results demonstrate that the gut microflora could potentially play a major role in proteolysis in the human colon.
\end{abstract}

\section{INTRODUCTION}

Ammonia concentrations in the large intestine of man have been reported to range between 3 and $44 \mathrm{~mm}$ (Wilson et al., 1968) and until recently it was considered that hydrolysis of endogenous urea by the gut microflora was the major source of this potentially toxic metabolite (Sabbaj et al., 1970; Summerskill \& Wolpert, 1970; Varel et al., 1974). Recent infusion experiments by Wrong et al. (1985), however, using ${ }^{15} \mathrm{~N}$-labelled urea, have suggested that urea hydrolysis does not occur to an appreciable extent in the colon, which would indicate that ammonia formation may result primarily from the deamination of amino acids produced by the breakdown of protein. Proteolysis is the first step in the utilization of protein by bacteria and the large oligopeptides which are initially formed are subsequently degraded into smaller peptides and amino acids (Hespell \& Smith, 1983), which can be either assimilated directly into microbial protein or fermented with the production of ammonia and volatile fatty acids (Prins, 1977; Allison, 1978). At present, few data are available concerning the extent and nature of protein degradation in the human colon, or of the proteolytic bacteria which may take part in this process, although it appears likely that a combination of microbial and pancreas derived proteolytic enzymes (trypsin, chymotrypsin and elastase) may be involved (Prins, 1977). This situation is in contrast to that of the rumen where studies have shown that rumen microorganisms (mainly bacteria) are completely responsible for protein breakdown (Blackburn \& Hobson, 1960; Brock et al., 1982) and where a range of proteolytic bacteria have been identified (Appleby, 1955; Blackburn \& Hobson, 1962; Fulghum \& Moore, 1963; Wallace \& Brammall, 1985).

In view of the current lack of information concerning $\mathbf{N}$ metabolism in general, and protein degradation in particular, in the human large intestine, the objectives of this study were to

Abbreviations: BSA, bovine serum albumin; VFA, volatile fatty acids. 
determine whether protein breakdown by gut micro-organisms could provide sufficient substrate to account for the high levels of ammonia production which occur in the colon, and to enumerate and identify the major proteolytic bacteria taking part in this process.

\section{METHODS}

Protein, ammonia and branched chain volatile fatty acids (VFA) in human intestinal contents. Gut contents (obtained from 6 sudden death victims within $4 \mathrm{~h}$ of death) and faecal samples (from 10 healthy volunteers) were homogenized with $0.1 \mathrm{M}$-sodium phosphate buffer $\mathrm{pH} 7.0$ in a stomacher to give $10 \%(\mathrm{w} / \mathrm{v})$ slurries. Samples $(10 \mathrm{ml})$ were then centrifuged at $30000 \mathrm{~g}$ for $8 \mathrm{~min}$ to produce cell-free supernatants, which were retained for analysis. Samples for protein estimations were precipitated with $10 \%(\mathrm{w} / \mathrm{v})$ TCA and centrifuged at $30000 \mathrm{~g}$ for $8 \mathrm{~min}$. The pellets were solubilized and resuspended in $1 \mathrm{M}-\mathrm{NaOH}$. Proteins were then determined by the Lowry method. Ammonia concentrations were measured by the phenol-hypochlorite method (Solorzano, 1969).

Fatty acid analysis. Branched chain VFA were detected by GC in a Pye model 204 gas chromatograph fitted with a flame ionization detector connected to a Pye-CDP1 computing integrator. The $1.4 \mathrm{~m}$ glass column $(4 \mathrm{~mm}$ i.d.) was packed with 10\% FFAP on 100-120 mesh Chromosorb W-AN DMCS (Pye-Unicam). Flow rates of the nitrogen carrier gas, hydrogen and air were set at 40,35 and $375 \mathrm{ml} \mathrm{min}^{-1}$ respectively. Temperatures of the injection port, column oven and detector were $175^{\circ} \mathrm{C}, 150^{\circ} \mathrm{C}$ and $175^{\circ} \mathrm{C}$ respectively. VFA were determined after removal of cells and particulate material by acidifying $0.5 \mathrm{ml}$ volumes with equal volumes of $1 \mathrm{M}-\mathrm{H}_{2} \mathrm{SO}_{4}$, followed by extraction into diethyl ether. The ether extract $(5 \mu \mathrm{l})$ was injected on to the column. Individual fatty acids were identified by comparison with retention times for authentic fatty acids, and quantitative results were obtained by preparing standard curves for each authentic fatty acid. These column conditions did not permit individual separation of the branched chain fatty acids 2-methylbutyrate and isovalerate.

Casein and bovine serum albumin (BSA) breakdown in faecal slurries. Approximately $160 \mathrm{~g}$ wet wt of fresh faeces were homogenized with $0.1 \mathrm{M}$-sodium phosphate buffer $\mathrm{pH} 7 \cdot 0$, which had previously been boiled and cooled under oxygen-free nitrogen, to give a $20 \%(\mathrm{w} / \mathrm{v})$ faecal slurry. Samples $(250 \mathrm{ml})$ of slurry were then transferred to 1 litre Gallenkamp reaction vessels and incubated with stirring for $48 \mathrm{~h}$ at $37^{\circ} \mathrm{C}$ to allow readily utilizable substrates to be removed. Anaerobic conditions were maintained by sparging slurries with oxygen-free nitrogen. After $48 \mathrm{~h}$ preincubation, $250 \mathrm{ml}$ of either phosphate buffer, phosphate buffer + casein $\left(20 \mathrm{mg} \mathrm{ml}^{-1}\right)$ or phosphate buffer + BSA $\left(20 \mathrm{mg} \mathrm{ml}^{-1}\right)$ was added to the reaction vessels. Samples $(2 \mathrm{ml})$ were subsequently removed from each reaction vessel and centrifuged at $15000 \mathrm{~g}$ for $10 \mathrm{~min}$ to remove particulate materials and cells before analysis. Ammonia concentrations were measured as previously described and proteins were determined as TCA-insoluble protein [precipitated by $10 \%(\mathrm{w} / \mathrm{v}) \mathrm{TCA}$ ] and TCA-soluble peptides [soluble in $10 \%(\mathrm{w} / \mathrm{v}) \mathrm{TCA}$ ] by the Lowry method. Separate standard curves were constructed for casein and BSA. VFA were determined as before except that caproic acid was used as an internal standard.

Fractionation of faeces. Fresh faeces from five subjects who had been eating normal Western diets were fractionated to determine the distribution of faecal proteolytic activity, according to the following procedure. Faeces $(40 \mathrm{~g})$ were homogenized in anaerobic reducing buffer in a stomacher to give a $10 \%(\mathrm{w} / \mathrm{v})$ faecal slurry. The anaerobic reducing buffer consisted of $0.1 \mathrm{M}$-sodium phosphate buffer $\mathrm{pH} 7.0$ containing $0.01 \%$ sodium ascorbate and $0.1 \%$ sodium thioglycollate. The faecal slurry was allowed to stand for $5 \mathrm{~min}$ to enable large particulate material to settle. Samples $(120 \mathrm{ml})$ were then removed and $20 \mathrm{ml}$ retained for assay of proteolytic activity (fraction 1). The remaining $100 \mathrm{ml}$ of slurry was centrifuged at $1500 \mathrm{~g}$ for $15 \mathrm{~min}$ at $4^{\circ} \mathrm{C}$ to give a crude particulate fraction (fraction 2) and a cell suspension, which was stored at $4{ }^{\circ} \mathrm{C}$ for later use. Fraction 2 was resuspended in $100 \mathrm{ml}$ reducing buffer and $20 \mathrm{ml}$ retained for measurement of proteolytic activity. The remainder was washed twice and resuspended in buffer to give a washed particulate fraction (fraction 5).

The cell suspension produced during the preparation of fraction 2 was centrifuged at $30000 \mathrm{~g}$ for $15 \mathrm{~min}$ at $4{ }^{\circ} \mathrm{C}$ and the resultant supernatant was then filtered through $0.2 \mu \mathrm{m}$ cellulose acetate filters to give a cell-free supernatant fraction (fraction 3). The bacterial pellet was washed twice and resuspended in $30 \mathrm{ml}$ reducing buffer, giving a washed cell fraction (fraction 4).

Measurement of proteolytic activities in faecal fractions. A modification of the method of Brock et al. (1982) with azocasein as substrate was used to determine proteolytic activities in faecal fractions $1-5$. Assays were done as follows: $1 \mathrm{ml}$ of sample suspension was dispensed in triplicate into $1.5 \mathrm{ml}$ capacity Eppendorf tubes and mixed with $0.2 \mathrm{ml}$ anaerobic reducing buffer. Reactions were initiated by the addition of $0.3 \mathrm{ml}$ azocasein stock solution, which gave an initial azocasein concentration of $10 \mathrm{mg} \mathrm{m}^{-1}$. The capped tubes were then incubated for $2 \mathrm{~h}$ at $37^{\circ} \mathrm{C}$. The reactions were terminated by transferring the tube contents into centrifuge tubes containing $1 \mathrm{ml} 10 \%$ $(w / v)$ TCA. Control tubes were incubated as above but without azocasein, which was added after inactivation of the sample with TCA. Inactivated samples were allowed to stand at room temperature for $30 \mathrm{~min}$, then were centrifuged at $27000 \mathrm{~g}$ for $8 \mathrm{~min}$ at $4^{\circ} \mathrm{C}$. Supernatant fluid $(1 \mathrm{ml})$ was then mixed with an equal volume of $1 \mathrm{M}$ $\mathrm{NaOH}$, and the absorbance of this solution was read at $450 \mathrm{~nm}$. 
Enumeration of proteolytic bacteria. Aerobic and anaerobic proteolytic bacteria were enumerated in five faecal samples by plate count methods, as follows. Faecal samples ( $1 \mathrm{~g}$ wet wt) were serially diluted in sterile Ringers solution, and suitable dilutions were plated in triplicate on either Wilkins-Chalgren anaerobe agar (containing GN or NS anaerobe supplements $)+2 \%(w / v)$ casein, azide agar $+2 \%(w / v)$ casein, nutrient agar $+2 \%(w / v)$ casein or the yeast extract/lactate medium of Malik et al. $(1968)+2 \%(w / v)$ casein, and solidified with $2 \%(w / v)$ agar.

All manipulations were done in a Gallenkamp anaerobic cabinet containing a $10 \% \mathrm{H}_{2}, 10 \% \mathrm{CO}_{2}, 80 \% \mathrm{~N}_{2}$ atmosphere. The Wilkins-Chalgren plates had been preincubated for $48 \mathrm{~h}$ at $37^{\circ} \mathrm{C}$ in the anaerobic cabinet before inoculation and, together with the yeast extract/lactate plates, were incubated in the anaerobic cabinet for up to $7 \mathrm{~d}$. After inoculation, the azide agar and nutrient agar plates were removed from the anaerobic cabinet and incubated under aerobic conditions at $37^{\circ} \mathrm{C}$ for up to $3 \mathrm{~d}$. Proteolysis was detected either by zones of clearing around colonies, which were enhanced by addition of acid mercuric chloride solution, or alternatively by precipitation of casein around proteolytic colonies (Martley et al., 1970).

Identification of proteolytic bacteria. Strictly anaerobic proteolytic bacteria were identified to genus level according to Gram reaction, morphology and fermentation products formed during growth in PY-glucose broth (Holdeman et al., 1977). Aerobic and facultative proteolytic bacteria were identified by methods described by Cowan (1974).

Proteolytic activities of Bacteroides spp. Bacteroides strains $\mathrm{B}_{16}, \mathrm{~B}_{22}, \mathrm{~B}_{31}$ and $\mathrm{B}_{41}$, which were isolated from faecal samples, and the type strains $B$. fragilis NIRD 2217, B. vulgatus NCTC 11154 and $B$. thetaiotaomicron NCTC 10582 were grown in batch culture in Gallenkamp 1 litre reaction vessels on Wilkins-Chalgren broth at $37^{\circ} \mathrm{C}$ for up to $96 \mathrm{~h}$. Anaerobic conditions and temperature were maintained as described earlier. Cells were harvested for measurements of proteolytic activity by centrifugation at $15000 \mathrm{~g}$ for $30 \mathrm{~min}$ at $4{ }^{\circ} \mathrm{C}$, the spent medium was retained, and the bacterial pellets were washed twice and resuspended with anaerobic reducing buffer. The washed cells and spent media were then assayed for proteolytic activity as before, using azocasein as substrate.

Production of proteolytic enzymes by bacteria isolated from faeces. Proteolytic activities of isolates obtained in this study were investigated as follows: Bacteroides strains $\mathrm{B}_{16}$ and $\mathrm{B}_{22}$, Clostridium $\mathrm{C}_{10}$ and Propionibacterium $\mathrm{P}_{1}$ were grown in 1 litre Gallenkamp reaction vessels on Wilkins-Chalgren broth as above. Streptococcus faecalis, Bacillus licheniformis, Bacillus subtilis and Staphylococcus $\mathrm{S}_{1}$ were similarly grown, except that cultures were sparged with sterile air in place of oxygen-free nitrogen. Proteolytic activities were determined during the exponential phase of growth as previously described.

Chemicals. Casein and BSA were obtained from BDH, azocasein and all other chemicals were obtained from Sigma. Bacteriological media were supplied by Oxoid.

\section{RESULTS}

\section{Analysis of intestinal contents}

Large quantities of soluble protein were found throughout the length of the large intestine (Table 1). Ammonia and branched chain VFA concentrations were low $\left(4.9\right.$ and $1.0 \mathrm{mmol} \mathrm{kg} \mathrm{g}^{-1}$ respectively) in ileal contents. In contrast, concentrations of both ammonia $\left(37.4 \mathrm{mmol} \mathrm{kg} \mathrm{kg}^{-1}\right)$ and branched chain VFA $\left(6.4 \mathrm{mmol} \mathrm{kg}{ }^{-1}\right)$ increased markedly in the caecum, and remained high in samples obtained from further down the large intestine.

\section{Protein breakdown by faecal slurries}

Casein was hydrolysed more rapidly and to a greater extent than was BSA in faecal slurries, as shown by the decrease in protein that was insoluble in 10\% TCA. Approximately $86 \%$ of the casein was hydrolysed during the $96 \mathrm{~h}$ incubation period, although only about $37 \%$ of this protein was actually utilized by the microflora, the remainder accumulating as TCA-soluble peptides (Fig. 1). In contrast, protein hydrolysis was less extensive with BSA, as only about $36 \%$ of the TCA-insoluble protein was hydrolysed (Fig. 2). However, virtually all the BSA that had been hydrolysed appeared to be utilized by the gut bacteria, as no TCA-soluble peptides accumulated.

VFA and ammonia were formed in large quantities when protein was added to slurries (Figs 1 and 2) but did not increase significantly in controls (Fig. 3), which confirmed that the formation of these metabolites resulted from the fermentation of the products of protein breakdown. Production of ammonia and VFA was greatest in casein-containing slurries $(49 \cdot 2 \mathrm{mM}$ and $29.8 \mathrm{mM}$, respectively) but was considerable in slurries with added BSA (32.0 mM and $25.5 \mathrm{~mm}$ 


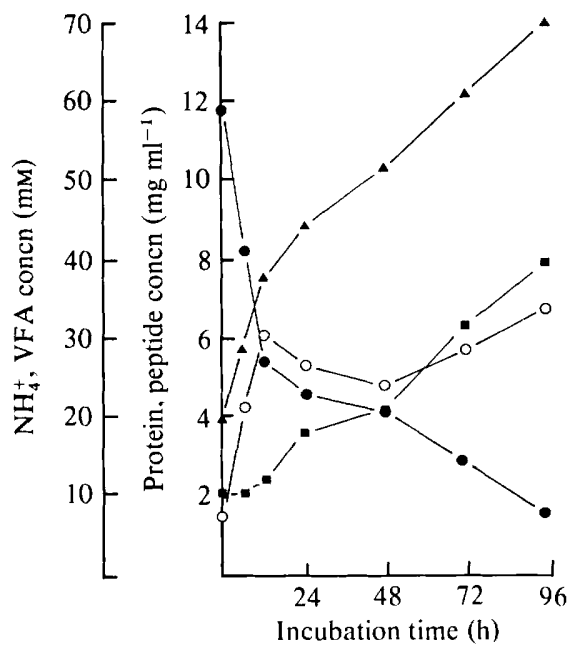

Fig. 1

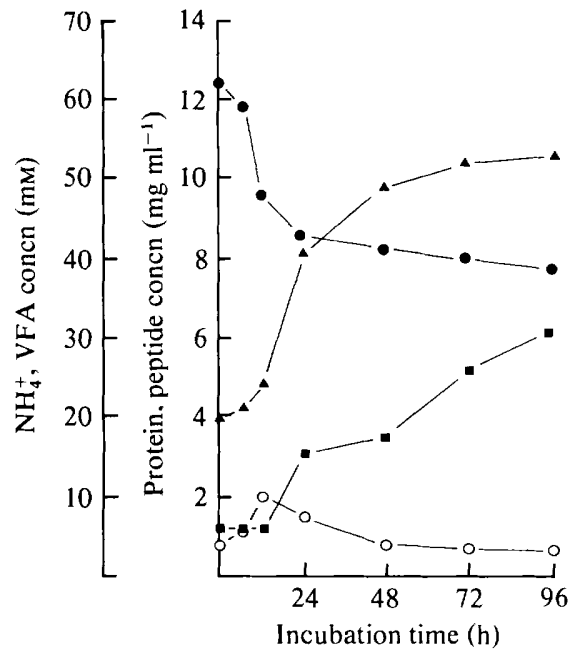

Fig. 2

Fig. 1. Breakdown of casein and production of $\mathrm{NH}_{4}^{+}$and VFA in a $10 \%(\mathrm{w} / \mathrm{v})$ faecal suspension incubated anaerobically at $37^{\circ} \mathrm{C}$ for $96 \mathrm{~h}$. Initial concentration of casein was $10 \mathrm{mg} \mathrm{ml}^{-1}$., , Protein; O, TCA-soluble peptides; $\Delta, \mathrm{NH}_{4}^{+} ; \square$, total VFA.

Fig. 2. Breakdown of BSA and production of $\mathrm{NH}_{4}^{+}$and VFA in a $10 \%(\mathrm{w} / \mathrm{v})$ faecal suspension incubated anaerobically at $37^{\circ} \mathrm{C}$ for $96 \mathrm{~h}$. Initial concentration of BSA was $10 \mathrm{mg} \mathrm{ml}^{-1}$., Protein; $\bigcirc$, TCA-soluble peptides; $\mathbf{\Lambda}, \mathrm{NH}_{4}^{+} ; \boldsymbol{\square}$, total VFA.

\section{Table 1. Protein, ammonia and branched chain VFA in human intestinal contents}

Gut contents were obtained from six sudden death victims within $4 \mathrm{~h}$ of death. Faecal samples were obtained from healthy volunteers.

\begin{tabular}{|c|c|c|c|c|c|c|c|}
\hline \multirow{2}{*}{$\begin{array}{l}\text { Sampling } \\
\text { location } \\
\text { in gut }\end{array}$} & \multirow{2}{*}{$\begin{array}{c}\text { No. } \\
\text { of } \\
\text { subjects }\end{array}$} & \multicolumn{2}{|c|}{$\begin{array}{c}\begin{array}{c}\text { Soluble protein } \\
\left(\mathrm{g} \mathrm{kg}^{-1}\right)\end{array} \\
\end{array}$} & \multicolumn{2}{|c|}{$\begin{array}{c}\mathrm{NH}_{4}^{+} \\
\left(\mathrm{mmol} \mathrm{kg}^{-1}\right)\end{array}$} & \multicolumn{2}{|c|}{$\begin{array}{l}\text { Total branched chai } \\
\text { VFA }\left(\mathrm{mmol} \mathrm{kg}^{-1}\right)\end{array}$} \\
\hline & & Range & Mean & Range & Mean & Range & Mean \\
\hline \multicolumn{8}{|l|}{ Small intestine } \\
\hline Jejunum & 6 & $3 \cdot 6 \cdot 74 \cdot 1$ & $25 \cdot 7$ & $0 \cdot 1-2 \cdot 2$ & $0 \cdot 9$ & 0 & 0 \\
\hline Ileum & 6 & $0 \cdot 3-19 \cdot 7$ & 11.7 & $0-18 \cdot 0$ & 4.9 & $0-3.7$ & $1 \cdot 0$ \\
\hline \multicolumn{8}{|l|}{ Large intestine } \\
\hline Caecum & 6 & $0 \cdot 1-15 \cdot 4$ & $5 \cdot 8$ & $12 \cdot 4-58 \cdot 5$ & $37 \cdot 4$ & $3 \cdot 7-8 \cdot 1$ & $6 \cdot 4$ \\
\hline Ascending & 6 & $0.9-16.7$ & $7 \cdot 3$ & $9 \cdot 0-58 \cdot 2$ & $26 \cdot 5$ & $1 \cdot 5-8 \cdot 7$ & 3.9 \\
\hline Transverse & 6 & $1 \cdot 2-21 \cdot 9$ & $13 \cdot 1$ & $7 \cdot 7-66 \cdot 0$ & $28 \cdot 7$ & $4 \cdot 2-9 \cdot 9$ & $6 \cdot 5$ \\
\hline Descending & 2 & $0 \cdot 2-24 \cdot 4$ & $12 \cdot 3$ & $33 \cdot 5-61 \cdot 9$ & $47 \cdot 7$ & $4 \cdot 5-7 \cdot 1$ & $5 \cdot 8$ \\
\hline Sigmoid & 2 & $7 \cdot 0-22 \cdot 4$ & $14 \cdot 7$ & $26 \cdot 3-28 \cdot 0$ & $27 \cdot 2$ & $4 \cdot 1-4 \cdot 3$ & $4 \cdot 2$ \\
\hline Rectum & 1 & $\longrightarrow$ & $14 \cdot 1$ & - & $49 \cdot 8$ & - & $11 \cdot 1$ \\
\hline Faeces & 10 & $5 \cdot 9-24 \cdot 3$ & $15 \cdot 8$ & $12 \cdot 5-42 \cdot 1$ & $20 \cdot 8$ & $3 \cdot 9-11 \cdot 0$ & $5 \cdot 7$ \\
\hline
\end{tabular}

respectively). Acetate $(8.3 \mathrm{mM})$, propionate $(6.1 \mathrm{mM})$, butyrate $(6.2 \mathrm{mM})$ and 2-methylbutyrate/ isovalerate $(6.4 \mathrm{mM})$ were the major fatty acids formed from casein (Table 2) whereas acetate $(16.9 \mathrm{mM})$ and butyrate $(6.0 \mathrm{mM})$ were the main fatty acids produced by slurries to which BSA had been added. Branched chain VFA constituted between $6 \%$ (BSA) and $29 \%$ (casein) of total VFA produced by these slurries.

\section{Distribution of proteolytic activity in faeces}

Total proteolytic activities recorded in $10 \%(\mathrm{w} / \mathrm{v})$ faecal suspensions prepared from the stools of five subjects varied between 0.35 and $1.98 \mathrm{mg}^{2}$ azocasein hydrolysed $\mathrm{h}^{-1}$ (ml suspension) $)^{-1}$ 


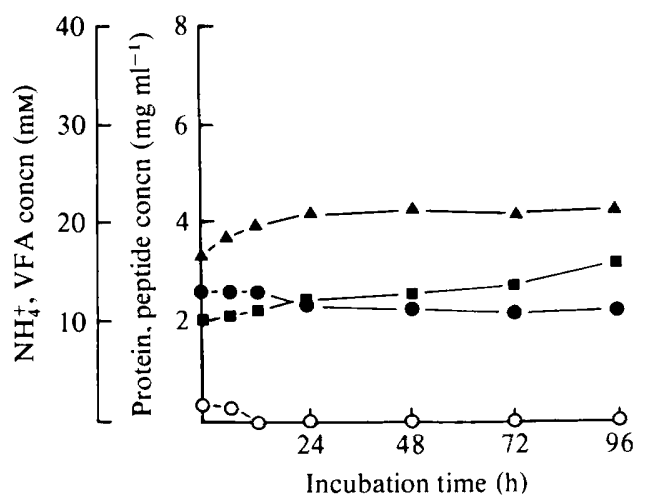

Fig. 3. Production of VFA and $\mathrm{NH}_{4}^{+}$in faecal slurry $(10 \%, \mathrm{w} / \mathrm{v})$ incubated anaerobically at $37^{\circ} \mathrm{C}$ for $96 \mathrm{~h}$ with no added protein. $\mathrm{O}$, Protein; $\mathrm{O}$, TCA-soluble peptides; $\boldsymbol{\Delta}, \mathrm{NH}_{4}^{+} ; \mathbf{\square}$, total VFA.

\section{Table 2. Production of $V F A$ from casein and $B S A$ in faecal slurries}

Casein or BSA $\left(10 \mathrm{mg} \mathrm{ml}^{-1}\right)$ was incubated at $37^{\circ} \mathrm{C}$ for $96 \mathrm{~h}$ under anaerobic conditions. Results are given as values corrected for VFA produced in slurries with no added protein.

VFA (mM) produced from:

\begin{tabular}{lcc}
\multicolumn{1}{c}{ VFA } & Casein & BSA \\
Acetic & 8.3 & 16.9 \\
Propionic & 6.1 & 1.0 \\
Isobutyric & 1.9 & 0.8 \\
Butyric & 6.2 & 6.0 \\
Isovaleric/2-methylbutyric & 6.4 & 0.8 \\
Valeric & 0.4 & $\mathrm{ND}$ \\
Isocaproic & 0.5 & $\mathrm{ND}$
\end{tabular}

ND, Not detected.

(Table 3), indicating that actual proteolytic activities in the faeces of these individuals ranged from 3.5 to $19.8 \mathrm{mg}$ azocasein hydrolysed $\mathrm{h}^{-1}$ (g faecal material) ${ }^{-1}$.

To establish the location of proteolytic activity in faecal contents, $10 \%(\mathrm{w} / \mathrm{v})$ slurries (fraction 1) were fractionated to produce a crude particulate fraction (fraction 2 ), cell-free supernatant fraction (fraction 3), washed cell fraction (fraction 4) and a washed particulate fraction (fraction $5)$. The distribution of proteolytic activity in these fractions varied considerably between individuals (Table 3). This was particularly illustrated in fraction 3 where $4.5-93.9 \%$ of total faecal proteolytic activity (as measured in fraction 1) was recovered. Measurements of proteolysis in fraction 5 showed that $37.5-75.9 \%$ of the original fraction 2 activity was retained after washing, indicating the presence of proteolytic bacteria, which strongly adhered to the particulate materials in faeces. Between 24.7 and $67.2 \%$ of total proteolytic activity was recovered in fractions 4 and 5 , demonstrating that a large proportion of faecal proteolytic activity was bound particulate material and bacterial cells.

\section{Enumeration, identification and proteolytic activities of faecal bacteria}

The most numerous proteolytic bacteria in the five faecal samples studie were identified as Bacteroides spp. $\left[1.0 \times 10^{11}-1.3 \times 10^{12}\right.$ (g dry wt faeces) $\left.^{-1}\right]$, on the basis of Gram stain, morphology and fermentation products formed in PY-glucose broth (Fig. 4). Proteolytic activities of Bacteroides spp. on agar plates were weak, and the narrow zones of proteolysis which formed around colonies only became apparent after extended incubations (5-7 d). Confirmation of the proteolytic activities of Bacteroides spp. was obtained by screening isolates 


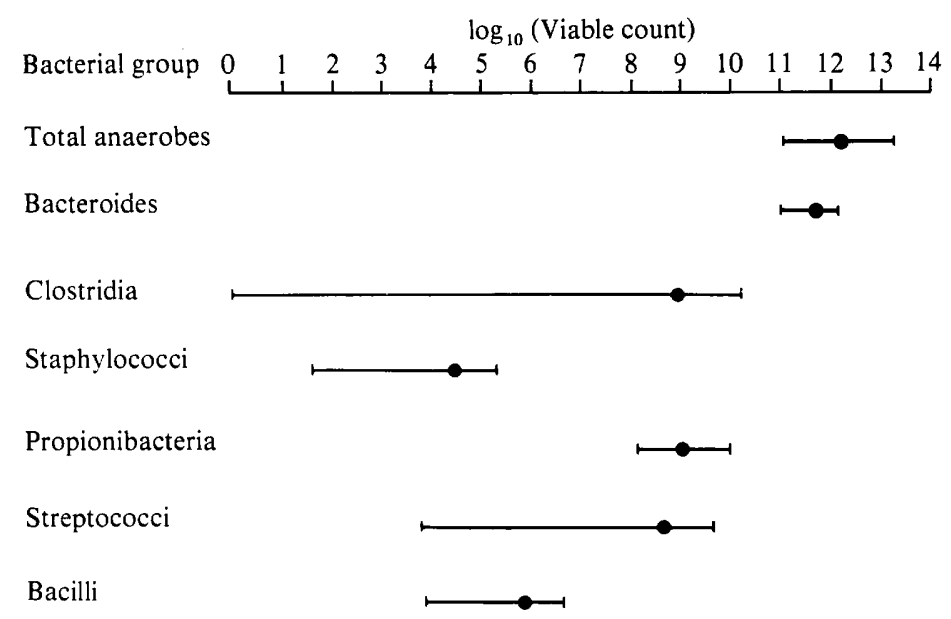

Fig. 4. Distribution of proteolytic bacteria in faeces obtained from five healthy subjects. Data are presented as $\log _{10}$ [cell counts ( $\mathrm{g}$ dry wt faeces) $\left.{ }^{-1}\right]$. Ranges are shown by bars, with mean values denoted by filled circles.

\section{Table 3. Distribution of proteolytic activity in the faeces of five individuals}

Faecal fractions 1-5 were obtained by differential centrifugation of $10 \%(\mathrm{w} / \mathrm{v})$ slurries as described in Methods. Results are means of three determinations.

Proteolytic activity

Sample

Faecal slurry, $10 \%(\mathrm{w} / \mathrm{v})$ (fraction 1$)$

Crude particulate fraction (fraction 2)

Cell-free supernatant fraction (fraction 3)

Washed cell fraction (fraction 4)

\begin{tabular}{|c|c|c|c|c|c|}
\hline \multirow[b]{2}{*}{ Subject } & \multicolumn{5}{|c|}{$\begin{array}{c}\text { Proteolytic activity } \\
\text { (mg azocasein hydrolysed } \mathrm{h}^{-1} \mathrm{ml}^{-1} \text { ) }\end{array}$} \\
\hline & 1 & 2 & 3 & 4 & 5 \\
\hline & 1.98 & $0 \cdot 35$ & $1 \cdot 15$ & 0.51 & 0.73 \\
\hline & 0.69 & $0 \cdot 16$ & $0 \cdot 29$ & $0 \cdot 15$ & $0 \cdot 19$ \\
\hline & 0.09 & 0.07 & 1.08 & $0 \cdot 21$ & 0.41 \\
\hline & 0.86 & 0.08 & $0 \cdot 10$ & 0.07 & 0.07 \\
\hline & 0.47 & 0.06 & $0 \cdot 22$ & $0 \cdot 11$ & $0 \cdot 11$ \\
\hline recovered in & $82 \cdot 8$ & $88 \cdot 6$ & $127 \cdot 8$ & $84 \cdot 3$ & $91 \cdot 8$ \\
\hline fractions & $67 \cdot 2$ & $40 \cdot 0$ & $27 \cdot 8$ & $35 \cdot 3$ & $24 \cdot 7$ \\
\hline
\end{tabular}

Washed particulate fraction (fraction 5)

Percentage of the total activity (fraction 1 ) recovered in fractions 2, 3 and 4

Percentage of the total activity recovered in fractions 4 and 5

$\mathbf{B}_{16}, \mathbf{B}_{22}, \mathbf{B}_{31}$ and $\mathbf{B}_{41}$, which were obtained in this study, together with the type strains $B$. fragilis NIRD $2217, B$. vulgatus NCTC 11154 and $B$. thetaiotaomicron NCTC 10582, for proteolytic activity with azocasein. The proteolytic enzymes of these bacteria were cell-associated [0.3$38.5 \mu \mathrm{g}$ azocasein hydrolysed $\mathrm{h}^{-1}\left(\mathrm{mg}\right.$ dry wt cells) ${ }^{-1}$; Table 4$]$. Other faecal proteolytic bacteria that occurred in lesser numbers were identified as belonging to the genera Propionibacterium, Clostridium, Streptococcus, Bacillus and Staphylococcus. These bacteria initially appeared to be more strongly proteolytic than the Bacteroides isolates, as large zones of casein precipitation were produced on agar plates. Subsequent experiments with pure cultures however showed that this was not necessarily the case. Protease activity of Bacteroides cultures $(0 \cdot 19-0.22 \mathrm{mg}$ azocasein hydrolysed $\left.\mathrm{h}^{-1} \mathrm{ml}^{-1}\right)$ was not significantly less than that of Staphylococcus $(0.23 \mathrm{mg}$ azocasein hydrolysed $\left.\mathrm{h}^{-1} \mathrm{ml}^{-1}\right)$ or Streptococcus $\left(0.34 \mathrm{mg}\right.$ azocasein hydrolysed $\left.\mathrm{h}^{-1} \mathrm{ml}^{-1}\right)$ cultures, and indeed was greater than that of Propionibacterium $(0.04 \mathrm{mg}$ azocasein hydrolysed $\left.\mathrm{h}^{-1} \mathrm{ml}^{-1}\right)$ and Clostridium cultures $\left(0.07 \mathrm{mg}\right.$ azocasein hydrolysed $\left.\mathrm{h}^{-1} \mathrm{ml}^{-1}\right)$. Protease production by the Bacillus isolates was considerable when grown under aerobic conditions ( $0.73-$ $1.50 \mathrm{mg}$ azocasein hydrolysed $\mathrm{h}^{-1} \mathrm{ml}^{-1}$ ) (Table 5). However, subsequent work has shown that when these isolates were grown under anaerobic conditions (in the absence of a terminal 
Table 4. Location of proteolytic activity in Bacteroides spp.

Bacteria were grown in batch culture at $37^{\circ} \mathrm{C}$ and cells were harvested during the exponential phase of growth.

\begin{tabular}{lcc}
\cline { 2 - 3 } \multicolumn{1}{c}{ Bacterium } & Washed cells & Spent media \\
Bacteroides B $_{16}$ & 23.0 & ND \\
Bacteroides B $_{22}$ & $11 \cdot 4$ & ND \\
Bacteroides B $_{31}$ & 14.6 & ND \\
Bacteroides B $_{41}$ & 7.6 & ND \\
B. thetaiotaomicron NCTC 10582 & 0.3 & ND \\
B. vulgatus NCTC 11154 & $12 \cdot 3$ & ND \\
B. fragilis NIRD 2217 & 38.5 & ND
\end{tabular}

ND, Not detected.

Table 5. Protease production by pure cultures of bacteria isolated from human faeces

Bacteria were grown in batch culture at $37^{\circ} \mathrm{C}$. Proteolytic activities were determined in cells harvested during the exponential phase of growth.

Proteolytic activity

[mg azocasein hydrolysed $\mathrm{h}^{-1}$
$\left.(\mathrm{ml} \text { culture })^{-1}\right]$

$\begin{array}{lll}\text { Bacteroides } \mathrm{B}_{16} & 0.22 & \text { Cell-bound } \\ \text { Bacteroides } \mathrm{B}_{22} & 0.19 & \text { Cell-bound } \\ \text { Streptococcus faecalis } \text { St }_{6} & 0.34 & \text { Cell-bound/extracellular* } \\ \text { Clostridium } \mathrm{C}_{10} & 0.07 & \text { Extracellular } \\ \text { Propionibacterium } \mathrm{P}_{1} & 0.04 & \text { Extracellular } \\ \text { Bacillus subtilis } & 1.50 & \text { Extracellular } \\ \text { Bacillus licheniformis } & 0.73 & \text { Extracellular } \\ \text { Staphylococcus } \mathrm{S}_{1} & 0.23 & \text { Cell-bound/extracellular* }\end{array}$

* Proteolytic activity detected on washed cells and in cell-free spent media.

electron acceptor such as $\mathrm{NO}_{3}^{-}$) there was little protease activity. This would suggest that in the large intestine protease formation by these bacteria would be negligible.

\section{DISCUSSION}

Considerable amounts of soluble protein were found in human intestinal contents and large quantities of ammonia and branched chain VFA (max. 66.0 and $11.0 \mathrm{mM}$ respectively) were generated throughout the colon (Table 1). These data indicate the presence of substantial proteolytic activity in the large gut and show that proteolysis and amino acid fermentation are not restricted to caecal contents. The low levels of ammonia and branched chain VFA in ileal contents, however, show that little amino acid fermentation occurs in the small intestine of man.

When casein and BSA were added to faecal slurries, TCA-soluble peptides, ammonia and VFA were produced (Figs 1 and 2). The faecal slurries were strongly proteolytic, since over $53 \%$ of protein in the slurry to which casein had been added was hydrolysed within $12 \mathrm{~h}$ (Fig. 1). Vince et al. (1976) showed that bacterial populations in faecal slurries remain substantially unchanged after incubation for $48 \mathrm{~h}$ at $37^{\circ} \mathrm{C}$. In order to remove readily utilizable substrates, faecal slurries in the present study were preincubated for $48 \mathrm{~h}$ before addition of casein or BSA. The rapid hydrolysis of protein, and the formation of metabolic end products in these slurries, confirmed that gut bacteria can survive and remain metabolically active for extended periods in vitro. 
Casein was hydrolysed to a greater extent than BSA in faecal slurries, indicating that, as in the rumen, the extent of protein breakdown in the large intestine of man is dependent upon protein structure as well as protein solubility (Mangan, 1972; Nugent \& Mangan, 1978). The ability of the gut microflora to hydrolyse protein to TCA-soluble peptides has previously been reported by Macfarlane \& Allison (1985), who investigated protein utilization using washed faecal bacterial cells. These experiments also showed that amino acids did not accumulate during protein breakdown. Ammonia concentrations in slurries amended with casein and BSA after $96 \mathrm{~h}$ incubation were 49.2 and $32.0 \mathrm{~mm}$ respectively, demonstrating that protein degradation can largely account for the high concentrations of ammonia that occur in the caecum and colon. These conclusions are supported by the work of Cummings et al. (1979), who showed in man that increased dietary protein intake resulted in increased ammonia concentrations in faeces. Total VFA concentrations in the human colon range between 80 and $130 \mathrm{~mm}$, and it is thought that these acids result mainly from the fermentation of plant cell wall polysaccharides such as cellulose, pectins and hemicelluloses (Cummings, 1981). However, in the present studies, considerable quantities of VFA were produced in faecal slurries to which casein $(29.8 \mathrm{mM})$ or BSA $(25.5 \mathrm{~mm})$ had been added, suggesting that protein degradation may also be an important source of VFA in the human gut.

Proteolytic activities measured in the faeces of five subjects ranged from 3.5 to $19.8 \mathrm{mg}$ azocasein hydrolysed $\mathrm{h}^{-1}$ (g faecal material) ${ }^{-1}$, which indicates considerable proteolytic potential. Proteolytic activities in human large intestinal contents are somewhat greater than those observed by Brock et al. (1982) in bovine rumen contents $\left[1.2 \mathrm{mg}\right.$ azocasein hydrolysed $\mathrm{h}^{-1}$ (g rumen contents) ${ }^{-1}$.

A wide range of human colonic bacteria have the ability to reduce azo dyes (Drasar \& Hill, 1974). In protease assays with azocasein as substrate, this could result in falsely low values being obtained. Brock et al. (1982), however, showed in studies with rumen contents that the colour released from azocasein was stable for up to $6 \mathrm{~h}$. Similar results obtained in this study confirm that, with short incubation periods, azo dye reduction does not significantly affect colour formation in protease assays.

Proteolytic activity in gut contents may arise from endogenous or microbial proteases. In the present study, the distribution of proteolytic activity varied considerably between faecal samples (Table 3), between 25 and $67 \%$ of total proteolytic activity being recovered in faecal fractions 4 and 5 . These results show that a substantial proportion of faecal proteolytic activity is bacterial in origin, being cell-bound or firmly attached to particulate material. Proteolytic activities observed in faecal fraction 3 ranged between 4.5 and $93.9 \%$ of total faecal proteolytic activity. Proteolysis in this faecal fraction probably results from the action of both soluble pancreatic and extracellular bacterial proteases. Evidence for the production of extracellular bacterial proteases in the colon was obtained by Macfarlane et al. (1985), who showed that approximately $36 \%$ of total faecal proteolytic activity was extracellular in faecal samples obtained from an individual lacking a pancreas.

It should be noted that proteolytic activities measured in faeces may not be representative of proteolytic activities throughout the large intestine, as Wiggins (1983) has shown that transit times of material through the gut can vary considerably $(12-120 \mathrm{~h})$. As digesta pass through the colon, water and metabolites such as $\mathrm{NH}_{4}^{+}$and VFA are absorbed through the gut wall. A consequence of this is that soluble materials which are not absorbed, such as proteins, are concentrated during transit. This may partly explain why such large variations in the amount and distribution of proteolytic activities were observed in the faecal samples examined (Table 3 ). In view of the severe difficulties involved in sampling directly from the colon, faecal proteolytic activities nevertheless provide a useful indication of the proteolytic potential of large intestinal contents.

The influence of diet on proteolytic activity in the human colon is largely unknown. In ruminants, ingested food immediately becomes available for fermentation, but in man, food residues entering the large intestine have been partly digested and physically altered during passage through the small intestine. Furthermore, a substantial amount of substrate available for fermentation in the colon is endogenous in origin, being composed of mucins, epithelial cells 
and small intestinal secretions (Wrong et al., 1985). Both of these factors, therefore, probably result in diet having a less marked effect on proteolytic activity than is the case in ruminant animals.

Bacteroides spp. were the numerically dominant proteolytic bacteria isolated [1.0 $\times 10^{11}-1 \cdot 3$ $\times 10^{12}$ (g dry wt faeces) $^{-1}$ ] (Fig. 4). Studies with pure cultures showed that the proteolytic enzymes of these bacteria were cell-associated (Table 4), which would indicate that Bacteroides may be largely responsible for the proteolytic activities observed in faecal fractions 4 and 5 (Table 3). If this is indeed the case, these bacteria would play a major role in protein breakdown in the large intestine, in addition to their more generally recognized activities as polysaccharide degraders (Salyers et al., 1981; Salyers \& Leedle, 1983). The cell-associated nature of the proteolytic enzymes of rumen Bacteroides is well documented (Blackburn, 1968; Hazlewood \& Edwards, 1981; Wallace \& Brammall, 1985) but proteolytic activity by non-rumen Bacteroides strains has so far received little attention. Moore \& Holdeman (1974), however, in a comprehensive study reported that some strains of colonic Bacteroides could hydrolyse gelatin.

Propionibacteria produce extracellular proteases (Ingram et al., 1983), and although they do not appear to be strongly proteolytic (Table 5), it is possible that by virtue of their relatively high numbers $\left[1.2 \times 10^{8}-1.0 \times 10^{10}\left(\mathrm{~g}\right.\right.$ dry wt faeces) $\left.{ }^{-1}\right]$ these bacteria could provide significant levels of proteolysis in the colon. In contrast, the apparently limited distribution of proteolytic clostridia and the low cell population densities of staphylococci, bacilli and to a lesser extent streptococci (Fig. 4) would appear to mitigate against these bacteria contributing significantly to large intestinal proteolysis.

In conclusion, the experimental results presented in this paper show that high levels of proteolytic activity occur in the large intestine of man and that a significant though variable proportion of this activity can be directly attributed to the microflora. Further studies are now required to identify the proteolytic enzymes present in the colon and to assess the qualitative effects of microbial and pancreatic proteases on protein breakdown in this organ.

\section{REFERENCES}

Allison, M. J. (1978). Production of branched-chain volatile fatty acids by certain anaerobic bacteria. Applied and Environmental Microbiology 35, 872-877.

APPLEBY, J. C. (1955). The isolation and classification of proteolytic bacteria from the rumen of the sheep. Journal of General Microbiology 12, 526-533.

Blackburn, T. H. (1968). Protease production by Bacteroides amylophilus strain H 18. Journal of General Microbiology 53, 27-36.

Blackburn, T. H. \& Hobson, P. N. (1960). Proteolysis in the sheep rumen by whole and fractionated rumen contents. Journal of General Microbiology 22, 272281.

Blackburn, T. H. \& Hobson, P. N. (1962). Further studies on the isolation of proteolytic bacteria from the sheep rumen. Journal of General Microbiology 29, 69-81.

Brock, F. M., Forsberg, C. W. \& Buchanan-SMith, J. G. (1982). Proteolytic activity of rumen microorganisms and effects of proteinase inhibitors. Applied and Environmental Microbiology 44, 561-569.

Cowan, S. T. (1974). Manual for the Identification of Medical Bacteria. Cambridge: Cambridge University Press.

Cummings, J. H. (1981). Short chain fatty acids in the human colon. Gut 22, 763-779.

Cummings, J. H., Hill, M. J., Bone, E. S., Branch, W. J. \& JEnkins, D. J. A. (1979). The effect of meat protein and dietary fiber on colonic function and metabolism. Part II. Bacterial metabolites in faeces and urine. American Journal of Clinical Nutrition 32, 2094-2101.

Drasar, B. S. \& Hill, M. J. (1974). Human Intestinal Flora. London \& New York: Academic Press.

Fulghum, R. S. \& Moore, W. E. C. (1963). Isolation, enumeration, and characteristics of proteolytic ruminal bacteria. Journal of Bacteriology 85, 808815.

Hazlewood, G. P. \& Edwards, R. (1981). Proteolytic activities of a rumen bacterium, Bacteroides ruminicola R8/4. Journal of General Microbiology 125, $11-$ 15.

Hespell, R. B. \& SMITH, C. J. (1983). Utilization of nitrogen sources by gastrointestinal tract bacteria. In Human Intestinal Microflora in Health and Disease, pp. 167-187. Edited by D. J. Hentges. London \& New York: Academic Press.

Holdeman, L. V., Cato, E. P. \& Moore, W. E. C. (editors) (1977). Anaerobic Laboratory Manual, 4th edn. Blacksburg, Virginia: VPI Anaerobe Laboratory.

INGRAM, E., Holland, K. T., Gowland, G. \& CUNLIFFE, W. J. (1983). Studies of the extracellular proteolytic activity produced by Propionibacterium acnes. Journal of Applied Bacteriology 54, 263-271.

Macfarlane, G. T. \& Allison, C. (1985). Utilization of protein by human gut bacteria. Journal of Applied Bacteriology 59, xix.

Macfarlane, G. T., Allison, C. \& Cummings, J. H. (1985). Distribution of proteolytic activity in the 
intestinal contents of man. Journal of Applied Bacteriology 59, xviii-xix.

Malik, A. C., Reinhold, G. W. \& Vedamuthu, E. R. (1968). An evaluation of the taxonomy of Propionibacterium. Canadian Journal of Microbiology 14, 1185-1191.

MANGAN, J. L. (1972). Quantitative studies on nitrogen metabolism in the bovine rumen. The rate of proteolysis of casein and ovalbumin and the release and metabolism of free amino acids. British Journal of Nutrition 27, 261-283.

Martley, F. G., Jayashankar, S. R. \& LawRence, R. C. (1970). An improved agar medium for the detection of proteolytic organisms in total bacterial counts. Journal of Applied Bacteriology 33, 363-370.

MOORE, W. E. C. \& Holdeman, L. V. (1974). Human fecal flora: the normal flora of 20 JapaneseHawaiians. Applied and Environmental Microbiology 27, 961-979.

Nugent, J. H. A. \& Mangan, J. L. (1978). Rumen proteolysis of fraction 1 leaf protein, casein and bovine serum albumin. Proceedings of the Nutrition Society 37, 48A.

PRINS, R. A. (1977). Biochemical activities of gut microorganisms. In Microbial Ecology of the Gut, pp. 73-183. Edited by R. T. J. Clarke \& T. Bauchop. London \& New York: Academic Press.

Sabbaj, J., SutTer, V. L. \& Finegold, S. M. (1970). Urease and deaminase activities in fecal bacteria in hepatic coma. In Antimicrobial Agents and Chemotherapy, pp. 181-185. Edited by G. L. Hobby. Washington, DC: American Society for Microbiology.

Salyers, A. A. \& Leedle, J. A. Z. (1983). Carbohydrate metabolism in the human colon. In Human Intestinal Microflora in Health and Disease, pp. 129 146. Edited by D. J. Hentges. London \& New York: Academic Press.
Salyers, A. A., Gherardini, F. \& O'Brien, M. (1981). Utilization of xylan by two species of human colonic Bacteroides. Applied and Environmental Microbiology 41, 1065-1068.

SolorzaNo, L. (1969). Determination of ammonia in natural waters by the phenolhypochlorite method. Limnology and Oceanography 14, 799-801.

Summerskill, W. H. J. \& WolperT, E. (1970). Ammonia metabolism in the gut. American Journal of Clinical Nutrition 22, 633-639.

Varel, V. H., Bryant, M. P., Holdeman, L. V. \& MOORE, W. E. C. (1974). Isolation of ureolytic Peptostreptococcus productus from feces using defined medium: failure of common urease tests. Applied Microbiology 28, 394-399.

Vince, A., Down, P. F., Morison, J., TwigG, F. J. \& WRONG, O. M. (1976). Generation of ammonia from non-urea sources in a faecal incubation system. Journal of Clinical Science and Molecular Medicine, 51, 313-322.

Wallace, R. J. \& BRammall, M. L. (1985). The role of different species of bacteria in the hydrolysis of protein in the rumen. Journal of General Microbiology 131, 821-832.

Wiggins, H. S. (1983). Gastroenterological functions of dietary fibre. In Dietary Fibre, pp. 205-219. Edited by G. G. Birch \& K. J. Parker. London: Applied Science Publishers.

Wilson, D. R., ING, T. S., Metcalfe-Gibson, A. \& WRONG, O. M. (1968). In vivo dialysis of faeces as a method of stool analysis. III. The effect of intestinal antibiotics. Clinical Science 34, 211-221.

Wrong, O. M., Vince, A. J. \& Waterlow, J. C. (1985). The contribution of endogenous urea to faecal ammonia in man, determined by ${ }^{15} \mathrm{~N}$ labelling of plasma urea. Clinical Science 68, 193-199. 